\title{
ERYTHROGENESIS IMPERFECTA OR CONGENITAL HYPOPLASTIC ANAEMIA (DIAMOND-BLACKFAN TYPE)
}

\author{
BY \\ O. D. FISHER and F. M. B. ALLEN \\ From the Department of Child Health, The Queen's University, Belfast
}

(RECEINED FOR PLBLICATION MAY 11, 1953)

Since Diamond and Blackfan described four cases of congenital hypoplastic anaemia in 1938 the condition has been frequently reported and the literature was fully reviewed by Palmén and Vahlquist in 1949.

Little has been added to the original description of the disease, which is a pure, red-cell anaemia in which there is a constant lack of reticulocytes. The erythroblasts in the bone marrow are slightly or moderately depressed while the white blood cells and platelets with their precursors are normal. The condition usually becomes manifest after a few months of life when anaemia develops and persists in spite of treatment although blood transfusion is of temporary benefit. The disease affects both sexes and has no familial tendency. There is no evidence of loss of blood or of haemolysis, and Gleiss and Greiner (1951) have shown that in such cases transfused red blood cells survive a period of 90 to 95 days. No toxic agent has been detected in this condition, which is considered to result from a failure of maturation of the red blood cell at the late normoblast stage. This was demonstrated by marrow cultures by Cathie (1950).

Although a maturation factor deficiency would seem to be the most likely cause, no such factor has so far been discovered. The usual haematinics, liver extracts, folic acid, vitamin B12 and iron in all forms as well as trace elements of copper, cobalt and manganese have no effect on this anaemia. The possibility of an endocrine disorder has led to the use of hormonal preparations such as thyroid extract, 'antuitrin', insulin, parathormone, adrenaline, testosterone and stilboestrol, but without success. Other drugs, including arsenic and vitamin preparations such as ascorbic acid and nicotinamide, as well as short wave diathermy to the long bones have also proved ineffective. Splenectomy has been followed by equivocal results and its value is difficult to assess.

The only beneficial treatment is repeated transfusions of blood; these are technically difficult in the infant and smaller child and there is always the possibility of a mis-matched transfusion. In longstanding cases this treatment is followed by a rise in the serum iron level according to Palmén and Vahlquist (1949), and haemosiderosis with pigmentation of the skin and enlargement of the liver was noted by Cathie (1950) and Lelong, Joseph, Polonowski, Desmonts and Colin (1951). On account of these hazards the following case of congenital hypoplastic anaemia is reported in view of the satisfactory response to A.C.T.H. and cortisone therapy.

\section{Case Report}

Carol McC. (Fig. 1) was born on December 24, 1949, as a full term infant but weighing only $4 \frac{1}{2} \mathrm{lb}$. (2 kg.).

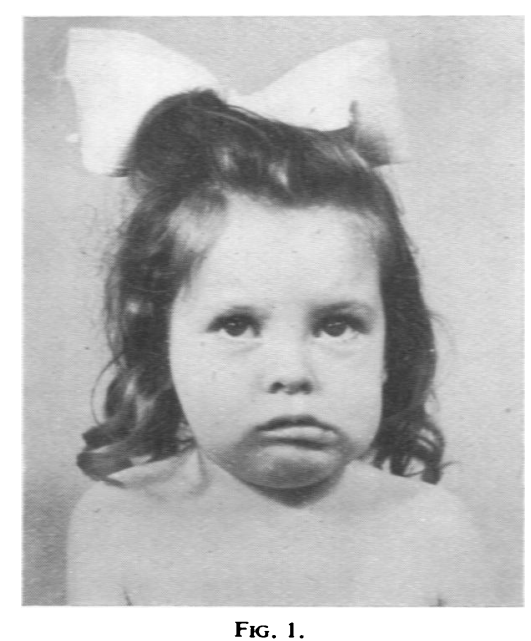

She was the twelfth child of a family in which there had been six miscarriages at the sixth month of pregnancy and one child stillborn at full term. The second child died, aged 5 months, of convulsions and the third child at 10 weeks of meningitis; the fourth and tenth children survived and are healthy. 
She was artificially fed on dried milk. Pallor was first noticed at 3 months of age, and failed to respond to iron given by mouth. At 7 months the pallor was intense, a haemic cardiac murmur was present and the spleen palpable; a blood transfusion was given. At 14 months a second blood transfusion was required and further haematological examination showed a condition typical of congenital hypoplastic anaemia.

On May 10, 1951, blood examination showed : Haemoglobin $52 \%(7.7 \mathrm{~g}$. per $100 \mathrm{ml}$.), red blood cells $2,580,000$ per c.mm., colour index $1 \cdot 0$, white blood cells 7,450 per c.mm., platelets 220,000 per c.mm., reticulocytes $<0.25 \%$. A blood film showed anisocytosis. A differential white cell count gave polymorphs $43 \%$, large lymphocytes $3 \%$, small lymphocytes $44 \%$, monocytes $10 \%$. The P.C.V. was $22 \%$, M.C.V. 84 c. $\mu$, M.C.H.C. $36 \%$, E.S.R. $45 \mathrm{~mm}$. per hour (corrected, $3 \mathrm{~mm}$. per hour), bleeding time $1 \mathrm{~min} .30 \mathrm{sec}$., clotting time 2 min. Red cell fragility was normal; a Coombs test was negative. The blood group was $O$ (IV) $R h$ negative.

The serum bilirubin level was $0.2 \mathrm{mg}$. per $100 \mathrm{ml}$. The Wassermann reaction was negative.

Bone marrow investigation showed that the myeloid series was normal, but there was marked hypoplasia of the erythroid series.

No urobilinogen or urobilin was shown. Gastric acidity was normal.

A radiograph of the chest, a barium meal and enema were normal. There was slight osteoporosis of the wrist but the bone age was normal. The Mantoux reaction was negative.

Since then the child has required blood transfusions at intervals of approximately two months, and other haematinics, folic acid, vitamin $\mathrm{B} 12$ and liver extract preparations have been given without effect (Fig. 2).

Clinically the child was well proportioned and well nourished with similar features to those described by Cathie (1950), of blonde colouring, snub nose, thick upper lip, wide-set eyes and an intelligent expression. The spleen could be palpated only after a blood transfusion but the liver was enlarged $1 \frac{1}{2}$ in. $(3.8 \mathrm{~cm}$.) below the costal margin. When anaemic, pallor and a haemic cardiac murmur were present.

On August 4, 1952, peripheral blood examination showed haemoglobin $71 \%$ (10.5 g. per $100 \mathrm{ml}$.$) , red blood cells$ $2,990,000$ per c.mm., colour index $1 \cdot 2$, white blood cells 5,400 per c.mm., platelets 173,000 per c.mm., reticulocytes $<0 \cdot 2 \%$. A blood film showed slight macrocytosis. The differential white cell count gave polymorphs $39 \%$, eosinophils $2 \%$, monocytes $4 \%$, Türk cells $1 \%$, large lymphocytes $2 \%$, small lymphocytes $52 \%$. The bone marrow showed hypoplasia of the erythroid series but normal myeloid activity (Table 1).
TABLE 1

BONE MARROW DIFFERENTIAL COUNTS

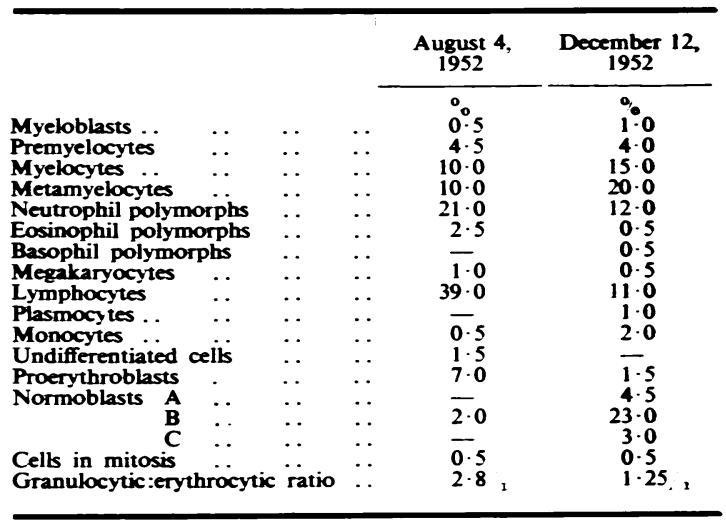

A course of A.C.T.H., $10 \mathrm{mg}$. six-hourly by intramuscular injection, was given for the next 14 days and was followed by a slight reticulocytosis while the haemoglobin level fell only $15 \%(2 \cdot 2 \mathrm{~g}$. per $100 \mathrm{ml}$.) during the next seven weeks (Fig. 3).

On September 29 a further transfusion of $300 \mathrm{ml}$. of packed red cells was given and on October 1 the haemoglobin was $96 \%(14 \cdot 2 \mathrm{~g}$. per $100 \mathrm{ml}$.) falling to $87 \%$ (12.9 g. per $100 \mathrm{ml}$.) on October 11 when oral cortisone,

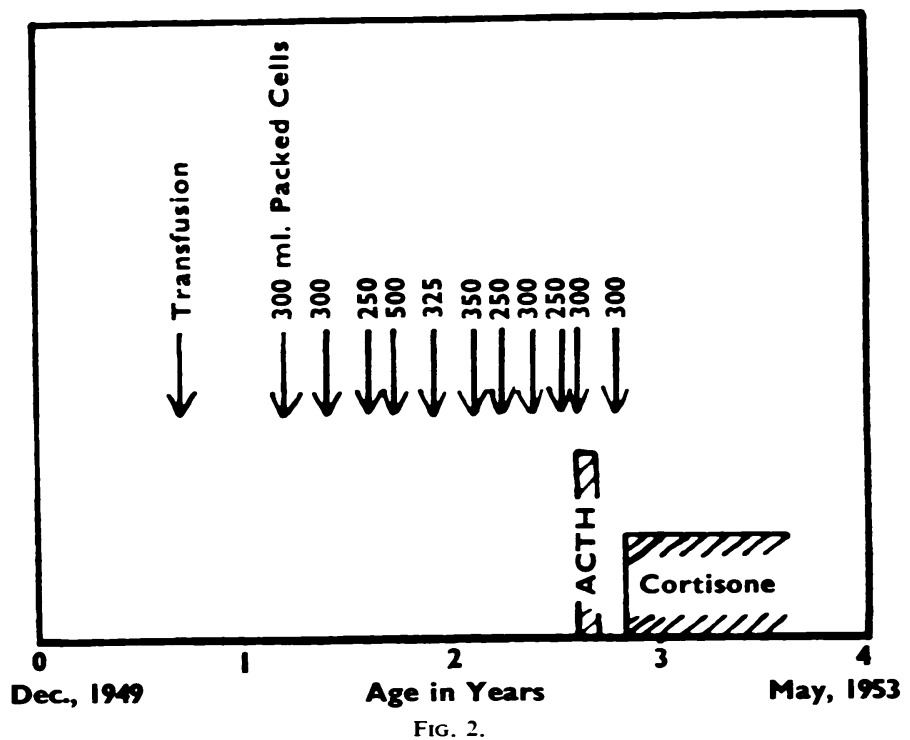

$25 \mathrm{mg}$. at 12-hourly intervals, was started. This was followed by a reticulocytosis, an increase in haemoglobin level and a marked depression of the eosinophil count (Fig. 4).

On December 8, as the haemoglobin level had reached $113 \%(16.7 \mathrm{~g}$. per $100 \mathrm{ml}$.) the dosage of cortisone was 


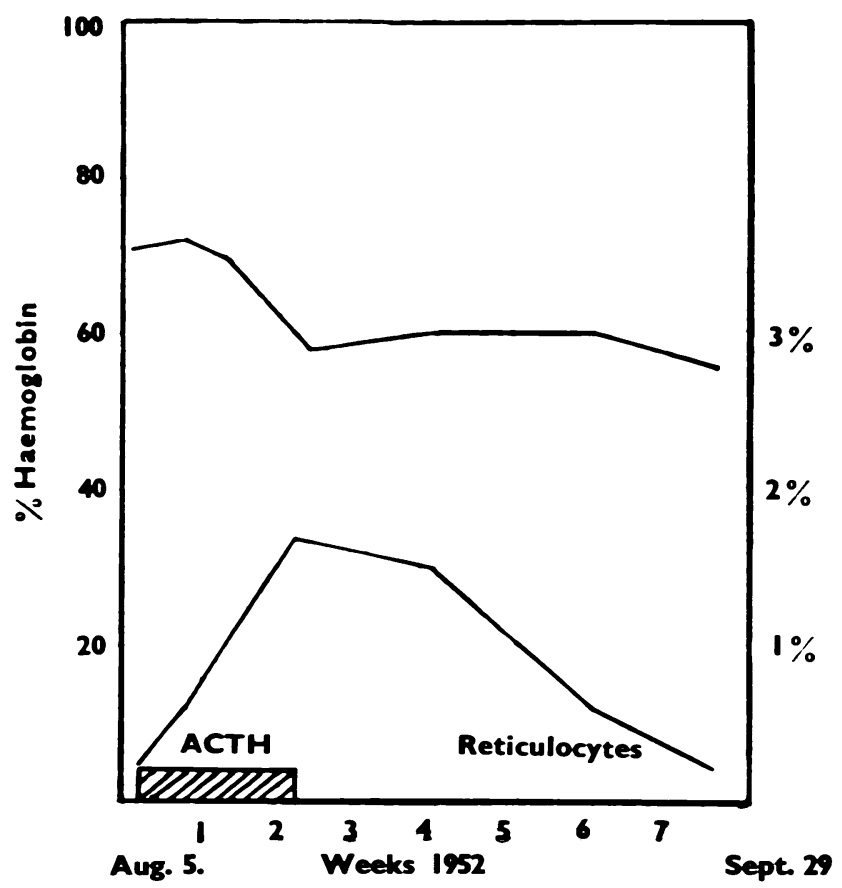

Fig. 3. reduced to $25 \mathrm{mg}$. daily, but three days later the child developed severe abdominal pain with vomiting and constipation. The abdomen was distended and tender, turbulent bowel sounds were heard, and a radiograph of the abdomen showed some gaseous distension of the small bowel. The possibility of hypokalaemia causing symptoms of an abdominal surgical emergency as described by Irons, Ayer, Brown and Amstrong (1951) was excluded as the serum electrolyte values were: potassium $18 \mathrm{mg}$. per $100 \mathrm{ml}$. (4.9 mEq. per l.), chloride ( $\mathrm{NaCl}$.) 605 mg. per $100 \mathrm{ml}$. (103.5 mEq. per 1.).

The electrocardiogram was also considered to be normal (Fig. 5).

At laparotomy a considerable amount of free fluid was present in the peritoneal cavity; a mass in the ascending colon disappeared when the bowel was delivered and the lower six inches $(15.8 \mathrm{~cm}$.) of the ileum were pink and distended. The lymph nodes were large and juicy throughout the mesentery of the small bowel. It was considered most likely that the condition was one of intussusception with spontaneous reduction. The post-operative course was uncomplicated. No blood transfusion was given and cortisone therapy was discontinued.

On December 16 the haemoglobin was $103 \%(15 \cdot 25$ g. per $100 \mathrm{ml}$.) and bone marrow examination revealed a normal red cell series, a totally different picture from

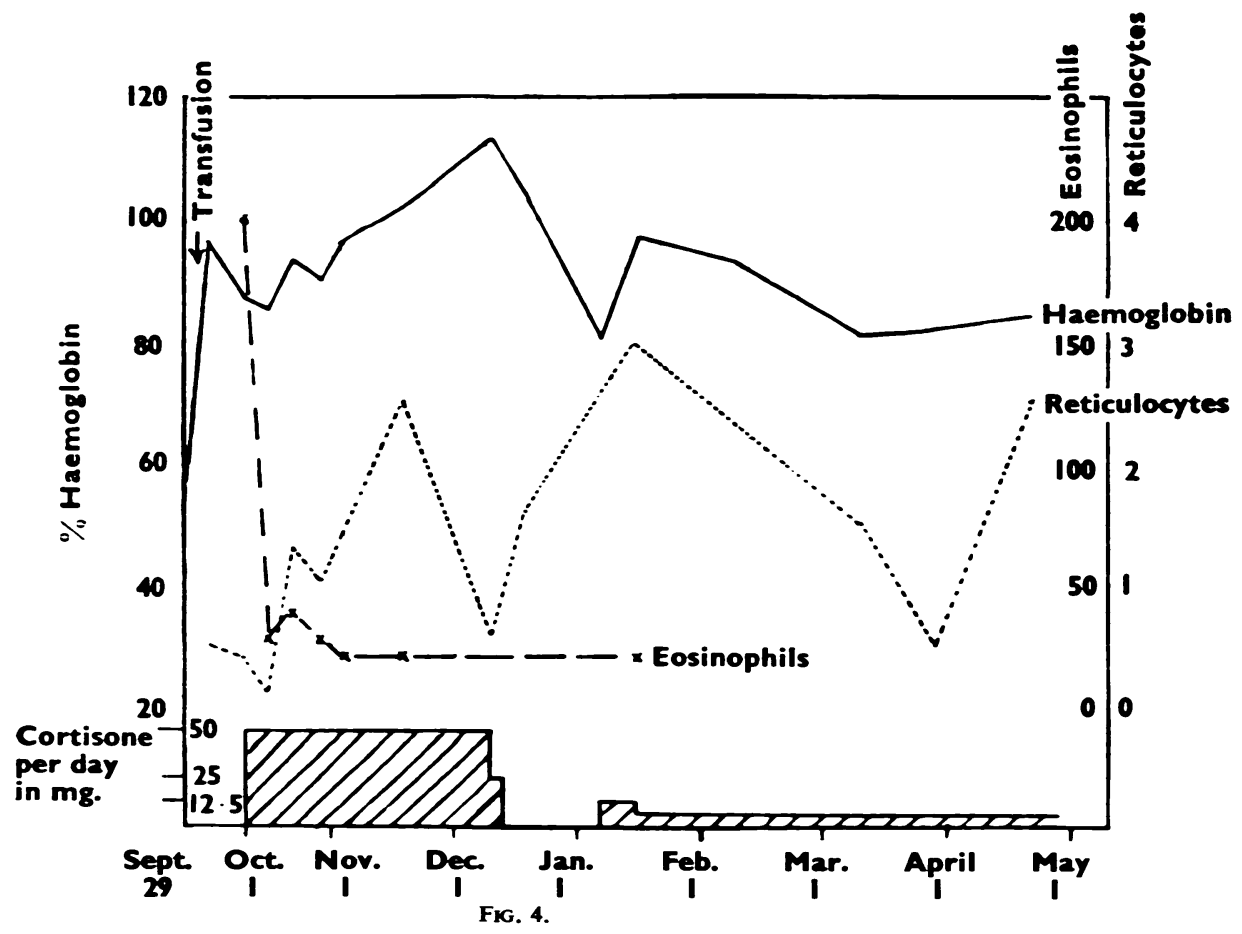




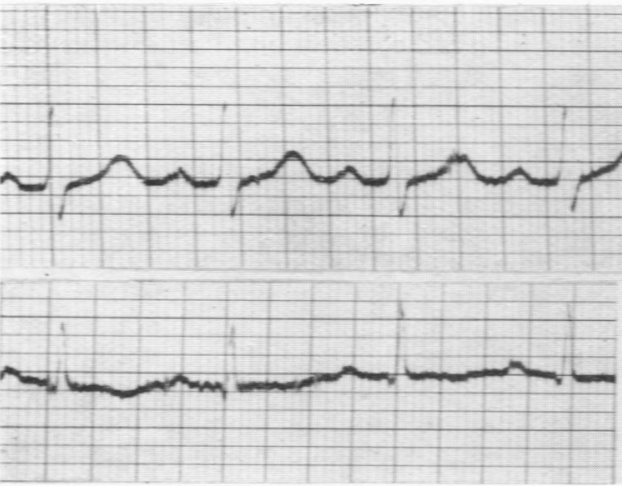

III

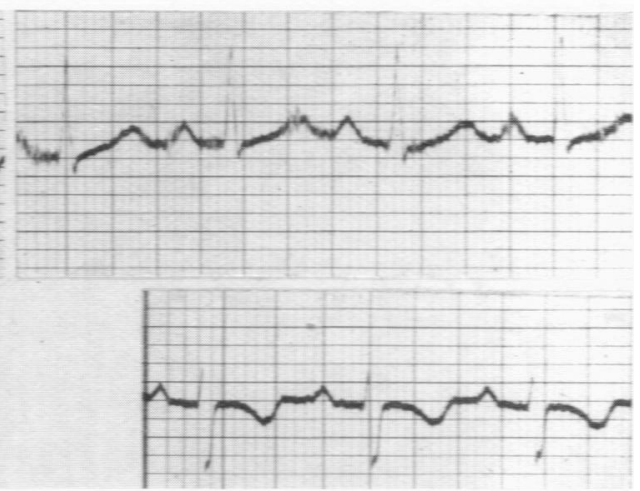

IV those previously reported as erythroid hypoplasia (Table 1). On January 5,1953 , the haemoglobin had fallen to $81 \%(12.0 \mathrm{~g}$. per $100 \mathrm{ml}$.) and cortisone was begun again in daily doses of $12.5 \mathrm{mg}$. together with $1 \mathrm{~g}$. of potassium chloride by mouth. A week later the haemoglobin had risen to $97 \%(14.35 \mathrm{~g}$. per $100 \mathrm{ml}$.) and the reticulocyte count to $3 \%$ so cortisone, $12.5 \mathrm{mg}$., was given on alternate days. This has been continued to date and the haemoglobin level maintained as shown in Fig. 4. The child remains well and active although noticeably undersized for her age, her height being only $25 \frac{1}{2}$ in. $(67 \cdot 3 \mathrm{c} . \mathrm{mm}$.), although her weight is $33 \frac{1}{2} \mathrm{lb}$. $(15 \cdot 2 \mathrm{~kg}$.).
Fig. 5.-Normal electrocardiogram on December 11.1952.

\section{Discussion}

This child shows the features which are characteristic of congenital hypoplastic anaemia, i.e. the onset in early life of a pure red-cell anaemia in which blood loss and haemolysis are absent, reticulocytes are lacking and there is no response to the usual haematinics. No toxic substance could be detected and would in any case be unlikely to exert such a prolonged effect. Bone marrow examination revealed erythroid hypoplasia, which in this case was confirmed by Dr.
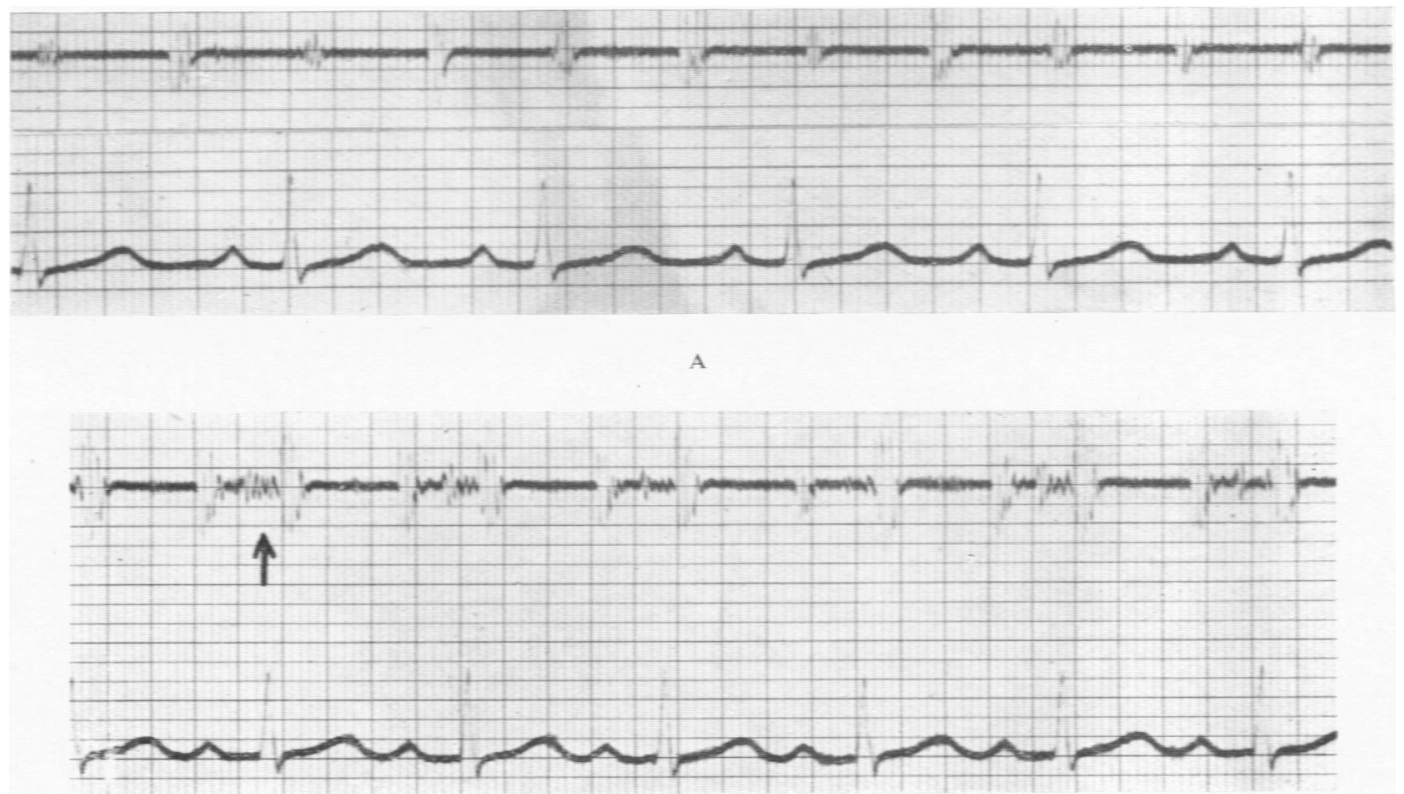

$B$

Fig. 6.-A. Phonocardiogram before blood transfusion. B. Phonocardiogram after blood transfusion showing triple rhythm ; the third heart sound is indicated by the arrow. 
Cathie, who kindly examined the slides which he considered similar to those of his own cases reported in 1950.

No congenital abnormalities are present such as occur with the anaemia of Fanconi's syndrome (1927), while the normal white cell and platelet counts exclude the possibility of primary splenic pancytopenia. Before A.C.T.H. and cortisone therapy was tried frequent blood transfusions were required. (The method employed was the scalp vein technique with general anaesthesia.) During transfusion triple rhythm was detected by auscultation and has been recorded by phonocardiograph (Fig. 6), indicating a further potential danger to such transfusions as overloading the circulation may lead to cardiac embarrassment.

The occurrence of spontaneous remission is reported in one of Diamond and Blackfan`s (1938) original cases. After two years of transfusions the red cell count remained about 3,500,000 per c.mm. Palmén and Vahlquist (1949) consider that there may be a stabilization at a low haemoglobin level in some cases when transfusions are withdrawn and to these they apply the term 'stationary hypoplastic anaemia: The general experience, however, is, as in this case, that the haemoglobin and red cell count fall progressively, and Diamond and Blackfan record a level of $10^{\circ}$ o haemoglobin $(1.5 \mathrm{~g}$. per $100 \mathrm{ml}$.) and 580.000 red blood cells per c.mm. in one case.

The possibility of such a remission coinciding in this child with A.C.T.H. and cortisone therapy is considered unlikely as after laparotomy cortisone therapy was deliberately withheld and the haemoglobin level fell from $103^{\circ}{ }_{0}(15.25 \mathrm{~g}$. per $100 \mathrm{ml}$.) to $81^{\circ}{ }_{0}\left(12.05 \mathrm{~g}\right.$. per $100 \mathrm{ml}$.) in 19 days. About $1^{\circ}{ }_{0}$ $(0.15$ g. per $100 \mathrm{ml}$.) haemoglobin per day has been the rate of fall in this particular patient.

This, together with the unprecedented rise in haemoglobin to $113^{\circ}{ }_{0}(16 \cdot 7 \mathrm{~g}$. per $100 \mathrm{ml}$.) and reticulocytosis leaves little doubt that A.C.T.H. and cortisone have been effective in causing maturation of the normoblasts as is also shown by the dramatic change in the bone marrow. The effect of A.C.T.H. and cortisone in blood disease such as haemolytic anaemia, sickle cell anaemia, thrombocytopenia and leukaemia are well known though the actual mechanism may not be fully understood.

Yoffey (1952) has investigated the effect of A.C.T.H. and cortisone on the bone marrow of guinea-pigs and he observed a significant increase in the myeloid and erythroid cells of the marrow suggesting that steroid compounds have a possible erythropoietic function. Finch, Crockett, Ross and Bayles (1951) have shown that anaemia in rheumatoid arthritis may respond to A.C.T.H. and cortisone. There is reticulocytosis and acceleration of red cell formation but no obvious change in the bone marrow, and in spite of continued therapy polycythaemia does not develop. However, polycythaemia is a well recognized feature of adrenocorticism or Cushing's syndrome and is presumably an effect of the adrenal steroids on the erythroid tissue.

In congenital hypoplastic anaemia the response to A.C.T.H. and cortisone may be a non-specific erythropoietic effect if the condition is primarily an inborn error of development of the late normoblast as suggested by Cathie (1950) and for which he employs the term 'erythrogenesis imperfecta'.

On the other hand the condition may be associated with an endocrine deficiency. The retardation of physical development so well illustrated in this child is not a constant feature of the condition but has been reported by Palmén and Vahlquist (1949) and Bernard, Inceman and Hovasse (1951). Adrenal function tests have not been undertaken in this child as cortisone therapy continues. This. in itself, may lead to many common side-effects such as a rapid gain in weight. pigmentation, acne. euphoria and electrolytic disturbances, but also to the more serious problem of masking the usual signs and symptoms of bacterial infection. Of particular importance is the activation or exacerbation of an unrecognized tuberculous process and possibly an increased liability to this infection. With this in mind frequent radiographs of the child's chest have been undertaken as, although the Mantoux reaction is negative, a falsely negative reaction may occur with A.C.T.H or cortisone therapy in the presence of active disease.

\section{Summary}

A further case of congenital hypoplastic anaemia is reported. Previous treatment of the condition and the dangers of repeated blood transfusions are reviewed. The successful response to A.C.T.H. and cortisone over a period of eight months is demonstrated and the mechanism of its effect discussed. The dangers of such therapy, if continued, are noted.

We should like to thank Dr. N. A. J. Carson for carrying out the haematological investigations.

\section{REFERENCES}

Bernard. J.. Inceman, S. and Hovasse, M. (1951). Arch. franc. Pediat., 28. 486.

Cathie, I. A. B. (1950), Archives of Disease in Childhood, 25, 313. Diamond, L. K. and Blackfan, K. D. (1938). Amer. J. Dis. Child.

Fanconi, G. (1927). Jb. Kinderheilk., 117, 257.

Finch, S. C., Crockett, C. L., Ross, J. F. and Bayles, T. B. (1951). Blood, 6. 1034.

Gleiss, J. and Greiner, H. (1951). Mschr. Kinderheilk., 99, 382. 
Irons, E. N., Aver, J. P., Brown, R. G. and Armstrong, S. H. (1951). J. Amer. med. Ass., 145, 861.

Lebng, M., Joseph, R., Polonowski, C., Desmonts, G. and Colin, J. (195i). Arch. franc. Pediat., 8, 473.

Palmén, K. and Vahlquist, B. (1949). Act. haemat., Basel, 4. 273.

Yoffey, J. M. (1952). Brit. med. J., 2, 722.

\section{Postscript}

Since May, 1953, the child has required no blood transfusion while on cortisone therapy. The haemoglobin has therefore ranged between 80 and $93 \%(11.8$ to $13.75 \mathrm{~g}$. per $100 \mathrm{ml}$.) and the reticulocytes between 0.5 and $1.25 \%$.

It is interesting to note that, as a further side-effect of cortisone, the child's hair has now changed from blonde to brunette. 